\title{
Role of Body Exhaust System in Reducing Peri-Prosthetic Joint Infection, Literature Review
}

\author{
Mohammad T Ghazavi ${ }^{1, *}$ \\ ${ }^{1}$ Scarborough Hospital, Toronto, Ontario, Canada \\ "Corresponding author: Mohammad T Ghazavi, Scarborough Hospital, Toronto, Ontario, Canada. Tel: +1-4168547077, Fax: +1-4167515270, E-mail: ghazavi@yahoo.com
}

Received 2016 September 10; Accepted 2016 September 29.

\begin{abstract}
Context: There is a need to determine if body exhaust suits which were initially used and recommended by Sir John Charnley has a role in minimizing bacterial shedding in the operating room.

Evidence Acquisition: The English literature search conducted for relevant articles. 14 articles were relevant to the role of body exhaust system in total joint replacement.

Results: There is controversial evidences regarding the role of body exhaust system in reducing pei-prosthetic joint infection but most evidences agree that its role in protecting operating room personnel could not be denied.

Conclusions: There is not enough evidence to indicate that use of body exhaust suits could reduce risk of infection, however there are some evidences showing increased protection of surgical team by using body exhaust system.
\end{abstract}

Keywords: Body Exhaust, Infection, Peri-Prosthetic, Joint

\section{Context}

There is a need to determine if body exhaust suits which were initially used and recommended by Charnley (1) has a role in minimizing bacterial shedding in the operating room. It has been shown that combination of body exhaust system and laminar air flow could decrease the bacterial counts in operating room environment (24). The benefits of this system and its role in reducing peri-prosthetic joint infection (PJI) are not supported in recently published studies. A literature review conducted to find out if use of body exhaust system is cost effective and could reduce the risk of PJI.

\section{Evidence Acquisition}

The English literature search conducted for relevant articles regarding use of Body Exhaust System at the time of total hip or knee arthroplasty. There were not too many articles studying its use, cost and benefits of Body Exhaust system in the operating rooms performing joint arthroplasty. 14 articles found to be relevant to the role of Body Exhaust System in total joint replacement.

\section{Results}

Body exhaust systems were originally used and recommended by Sir John Charnley to reduce the number of bac- teria in the operating rooms (1). The benefits of body exhaust suits discussed by Ritter et al. and Lidwell et al. They found that it could be more effective when combined with laminar flow conditions (2-4). Ritter et al. found that body exhaust suits could decrease bacterial counts of $69 \%$ in circulating compared with surgical scrubs alone and $38 \%$ compared with standard gowns (4). Illingworth et al. described that it could function as a fluid barrier and protect the operating room staff as well. They reaffirmed the role of decreasing bacterial shedding (5). If we combine body exhaust system with laminar air flew, airborne bacterial counts could be decreased to 1 colony forming unit (CFU) per cubic meter $(3,6)$. Lidwell et al in a multicenter randomized controlled study involving 8052 patients demonstrated a $75 \%$ reduction in the prevalence of infection with body exhaust suits combined with laminar flow (3).

Namba et al evaluated 30491 patients in a large integrated healthcare system to find out surgical factors that are associated with deep surgical site infection (SSI) after total hip replacement (THR) between 2001 and 2009. They used Kaiser permanente total joint replacement registry (TJRR) to identify Patient characteristics, surgical details, surgeon and hospital volumes, and SSIs. They used Proportional-hazard regression models to assess risk factors for SSI. They found in 155 out of 30491 patients who developed infection ( $0.51 \%$ incidence), female gender, obesity, the ASA score $\geq 3$ were associated with SSI. Other fac- 
tors as age, diagnosis diabetes and race were not associated with SSI. Surgical factors like surgeon, hospital volumes, use of antibiotic laden cement, fixation method, laminar flow, body exhaust system, surgical approach and fellowship training had no association with SSI. Only bilateral procedure had association with increase rate of SSI (7).

In a randomized prospective study Der Tavitian et al. (8) evaluated use of body exhaust system versus Rotecno occlusive clothing (Rotecno clothing is made of a hydrophobic, spun-laced, $70 \mathrm{~g} / \mathrm{m}^{2}$ polyester-pulp nonwoven) material. They used bacterial count in the air to assess the effectiveness of two systems. The incidence of recovered bacteria from the wounds was $62 \%, 64 \%$ from body exhaust system and $60 \%$ from Rotecno. They did not find any correlation between the air and wound count $(r=-0.011$, Spearman's). Rotecno occlusive clothing showed less effective than Body Exhaust System because of higher air bacterial count but they showed the same in wound bacterial count. They concluded that Rotecno clothing is more comfortable and economic. They recommended using wound count with TSMI method when comparing variables in UCA (8).

Chauveaux conducted a literature review and showed that that impeccable surgical technique and operating room behavior are clearly essential but effects of laminar airflow, body exhaust system and patient preparation techniques are contravertial (9).

Young et al. thought that air and particles could be moved through the unsealed area of the gown to the operating field. They used fluorescent powder to cover surgeon's hands and photographed the air particles under UV light. They compared space suit gowns with regular conventional gowns. There was no powder migration in conventional gowns. It could explain why infection rate is more when Space Suit gowns are used. They recommended to use Space Suits with sealant tape around the inner gloves only for personal protection (10).

Kapadia $\mathrm{BH}$ et al performed a systematic literature review and included all relevant articles to identify studies that assess the efficacy of pre-, peri- and post-operative infection prevention strategies in the setting of total hip or knee arthroplasty. Their preference was given to randomized-controlled trials, data from national registries and meta-analyses within the past 5 years from the date of their review. The results of their literature search returned 549 articles that addressed infection in total joint arthroplasty, of which 71 specifically addressed infection prevention. They concluded that traditionally accepted methods of prophylaxis such as laminar-flow operating rooms and body exhaust suits may raise the infection rate (11).

Young et al. also conducted a systematic literature review to compare the effect of negative-pressure Charnley- type body exhaust system with modern positive-pressure surgical helmet systems in reducing rates of deep infection in arthroplasty procedures. They concluded that using modern surgical helmet system did not show reduction in contamination or deep infection in arthroplasty surgery (12).

Illingworth et al. in a comprehensive publication discussed Preoperative, perioperative, intraoperative and postoperative measures in minimizing infection and optimizing patient outcomes in total joint arthroplasty (5). They concluded that despite the popularity of body exhaust suits in arthroplasty, their use remains controversial (5).

Hooper et al. used New Zealand national joint register to analyze 51,485 primary total hip replacements and 36,826 primary total knee replacements (TKR) for factors effective in reducing infection. They showed that the rate of infection could not be reduced with the use of body exhaust system and laminar airflow (13).

Tayton ER et al. also used the New Zealand joint registry database to analyze PJI at six and 12 months after surgery. They evaluated 64566 primary TKRs that were registered between 1999 and 2012 with minimum one year follow up. Their multivariate analysis showed that using surgical helmet system has a trend towards significance for deep infection. They concluded that there is no evidence in favor of modern surgical helmet system decreasing PII, they may even increase the risk of infection in primary TKR (14).

\section{Conclusions}

No strong evidence was found to support that use of body exhaust suits could reduce risk of infection, even some evidences showed that the incidence of infection could be higher in cases with use of body exhaust system; however there are some evidences showing increased protection of surgical team by using body exhaust system.

\section{References}

1. Charnley J. Postoperative infection after total hip replacement with special reference to air contamination in the operating room. Clin Orthop Relat Res. 1972;87:167-87. [PubMed: 4562188].

2. Lidwell OM, Lowbury EJ, Whyte W, Blowers R, Stanley SJ, Lowe D. Effect of ultraclean air in operating rooms on deep sepsis in the joint after total hip or knee replacement: a randomised study. Br Med J (Clin Res Ed). 1982;285(6334):10-4. [PubMed: 6805791].

3. Lidwell OM. Air, antibiotics and sepsis in replacement joints. J Hosp Infect. 1988;11 Suppl C:18-40. [PubMed: 2899118].

4. Ritter MA, Eitzen HE, Hart JB, French ML. The surgeon's garb. Clin Orthop Relat Res. 1980(153):204-9. [PubMed: 7449218].

5. Illingworth KD, Mihalko WM, Parvizi J, Sculco T, McArthur B, el Bitar Y, et al. How to minimize infection and thereby maximize patient outcomes in total joint arthroplasty: a multicenter approach.J Bone Joint Surg Am. 2013;95(8):50. 
6. Der Tavitian J, Ong SM, Taub NA, Taylor GJ. Body-exhaust suit versus occlusive clothing. A randomised, prospective trial using air and wound bacterial counts. J Bone Joint Surg Br. 2003;85(4):490-4. [PubMed: 12793550].

7. Namba RS, Inacio MC, Paxton EW. Risk factors associated with surgical site infection in 30,491 primary total hip replacements. J Bone Joint Surg Br. 2012;94(10):1330-8. doi: 10.1302/0301-620X.94B10.29184. [PubMed: 23015556].

8. Der Tavitian J, Ong SM, Taub NA, Taylor GJS. Body-exhaust suit versus occlusive clothing. Bone Joint J. 2003;85(4):490-4.

9. Chauveaux D. Preventing surgical-site infections: measures other than antibiotics. Orthop Traumatol Surg Res. 2015;101(1 Suppl):S77-83. doi:10.1016/j.otsr.2014.07.028. [PubMed: 25623269].

10. Young SW, Chisholm C, Zhu M. Intraoperative contamination and space suits: a potential mechanism. Eur J Orthop Surg Traumatol. 2014;24(3):409-13. doi: 10.1007/s00590-013-1178-1. [PubMed: 23412319].

11. Kapadia BH, Pivec R, Johnson AJ, Issa K, Naziri Q, Daley JA, et al. Infec- tion prevention methodologies for lower extremity total joint arthroplasty. Expert Rev Med Devices. 2013;10(2):215-24. doi:10.1586/erd.12.76. [PubMed: 23480090].

12. Young SW, Zhu M, Shirley OC, Wu Q, Spangehl MJ. Do 'Surgical Helmet Systems' or 'Body Exhaust Suits' Affect Contamination and Deep Infection Rates in Arthroplasty? A Systematic Review. J Arthroplasty. 2016;31(1):225-33. doi: 10.1016/j.arth.2015.07.043. [PubMed: 26321627].

13. Hooper GJ, Rothwell AG, Frampton C, Wyatt MC. Does the use of laminar flow and space suits reduce early deep infection after total hip and knee replacement?: the ten-year results of the New Zealand Joint Registry. J Bone Joint Surg Br. 2011;93(1):85-90. doi: 10.1302/0301620X.93B1.24862. [PubMed: 21196549].

14. Tayton ER, Frampton C, Hooper GJ, Young SW. The impact of patient and surgical factors on the rate of infection after primary total knee arthroplasty: an analysis of 64,566 joints from the New Zealand Joint Registry. Bone Joint J. 2016;98-B(3):334-40. doi: 10.1302/0301620X.98B3.36775. [PubMed: 26920958]. 